\title{
Pengaruh Penambahan Jamur Tiram Putih (Pleurotus oestreatus) dan Tepung Tapioka Terhadap Sifat Organoleptik Kerupuk
}

\author{
Anisa Nur Baitirahman ${ }^{\text {a,1,*, Yunda Maymanah Rahmadewi }}{ }^{\text {a,2 }}$, Palupi Melati Pangastuti a,3 \\ ${ }^{a}$ Bisnis Jasa Makanan UAD, J1. Pramuka No 42 Yogyakarta, 55161, Indonesia \\ ${ }^{1}$ anisanurbaitirahman@gmail.com, ${ }^{2}$ yunda.maymanah@culinary.uad.ac.id, ${ }^{3}$ palupi.melati@culinary.uad.ac.id \\ *penulis korespondensi
}

\begin{abstract}
Crackers are dry, light and porous food products. Currently, developing crackers are nonprotein crackers. The addition of oyster mushrooms is expected to improve the quality and nutritional value of crackers. This experiment aims to determine the effect of adding oyster mushrooms and tapioka flour to the organoleptic properties of crackers. The experimental design used was the Randomized Block Design method with proportion of oyster mushrooms and tapioka factor with six levels of treatment (300: 150; 400: 200; 300: 300; 190: 190; 200: 400; 120: 240). The proportion of oyster mushroom and tapioka in making crackers has a significant influence on the level of crispness, color, pores, and aroma and taste. From the experiments conducted stated that the best proportion for oyster mushroom crackers is 200: 400.
\end{abstract}

Keywords : crackers, oyster mushroom, tapioka flour

\begin{abstract}
ABSTRAK
Kerupuk merupakan produk pangan yang bersifat kering, ringan, dan porous. Saat ini kerupuk yang berkembang adalah kerupuk tidak berprotein. Penambahan jamur tiram diharapkan dapat meningkatkan kualitas serta nilai gizi dari kerupuk. Percobaan ini bertujuan untuk mengetahui pengaruh penambahan jamur tiram dan tepung tapioka terhadap sifat organoleptik kerupuk. Rancangan percobaan yang digunakan adalah metode Rancangan Acak Kelompok (RAK) dengan faktor tunggal yaitu proporsi jamur tiram dan tapioka dengan enam level taraf perlakuaan (berturutturut $2: 1 ; 1: 1 ; 1: 2$ ) dengan 2 kali ulangan. Proporsi jamur tiram dan tapioka dalam pembuatan kerupuk memberi pengaruh nyata terhadap tingkat kerenyahan, warna, pori-pori, serta aroma dan rasa. Dari percobaan yang dilakukan menyatakan bahwa proporsi terbaik untuk kerupuk jamur tiram adalah 1:2.
\end{abstract}

Kata Kunci : jamur tiram, kerupuk, tepung tapioka

\section{Pendahuluan}

Kerupuk merupakan produk pangan yang bersifat kering, ringan, dan porous. Dalam praktiknya kerupuk diolah dengan bahan dasar tepung tapioka, air, garam, bawang putih, dan gula. Di Indonesia kerupuk sudah tidak asing lagi di telinga. Awalnya kerupuk diolah hanya sebagai makanan pendamping nasi, namun saat ini hampir setiap kuliner menjadikan kerupuk sebagai pendamping bahkan menu utama pada masakan salah satunya adalah seblak. Kerupuk sudah ada di pulau Jawa sejak Abad ke-9 M dalam prasasti Batu Pura menuliskan bahwa kerupuk rambak terbuat dari kulit kerbau atau sapi. 
Menurut Theodora (2013), jenis kerupuk dibagi menjadi dua yaitu kerupuk berprotein dan tidak berprotein. Kerupuk yang berkembang saat ini kebanyakan adalah kerupuk tidak berprotein. Jamur Tiram merupakan bahan makanan bernutrisi dengan kandungan protein tinggi, kaya vitamin dan mineral, rendah karbohidrat, lemak dan kalori (Sumarni, 2006). Oleh karena itu, penambahan jamur tiram sebagai sumber protein kerupuk sehingga dapat meningkatkan nilai guna kerupuk jamur tersebut. Kandungan protein dari jamur tiram adalah sebesar 17,50\% dan serat kasarnya sebesar 14,12\% (Ardiansyah, 2013).

Dalam penelitian yang dilakukan oleh Purnomo et.al (1984), menyatakan bahwa kandungan protein yang tinggi cenderung menurunkan daya kembang kerupuk. Semakin banyak penambahan bahan baku bukan pati semakin kecil pengembangan kerupuk pada saat penggorengan dan akan mempengaruhi tingkat kerenyahan kerupuk. Kualitas kerupuk yang baik memiliki kenampakan pori yang rapat. Kenampakkan pori yang rapat itulah disebabkan oleh kandungan protein.

Penggunaan putih telur pada pembuatan kerupuk dimaksudkan sebagai pengemulsi serta pengikat komponen-komponen adonan. Putih telur juga berperan sebagai pengikat udara dan menahannya sebagai gelembung. Kerupuk yang ditambahkan telur dapat meningkatkan rasa, kerenyahan dan pengembanhan volume (Sutrisno, 2009).

\section{Metode Penelitian}

\subsection{Alat dan bahan}

Alat yang digunakan dalam penelitian ini yaitu timbangan, strainer, panci, blender, spatula, wajan dan plastic. Sedangkan untuk bahan yang digunakan yaitu jamur tiram, tepung tapioka, putih telur, merica, garam, gula, bawang putih dan air.

\subsection{Pembuatann kerupuk jamur}

Pembuatan kerupuk jamur menggunakan acuan Martawijaya dan Nurjayadi (2010) yang dimodifikasi yang dimulai dengan penyortiran jamur tiram kemudian dibersihkan. Setelah itu dilakukan pengkusan selama 10 menit, lalu dihaluskan menggunakan blender. Jamur tiram yang sudah halus dicampur tepung tapioka dan diaduk kemudian diberikan tambahan bumbu. Adonan yang sudah tercampur rata dibentuk dengan menggunakan plastik dengan diameter $7 \mathrm{~cm}$ dan panjang $15 \mathrm{~cm}$ sebagai pembungkus dan dikukus selama 30 menit. Adonan selanjutnya didinginkan dan didiamkan selama 6 jam sehingga mengeras. Adonan yang telah keras dipotong tipis-tipis dengan ketebalan $\pm 1-2 \mathrm{~mm}$ selanjutnya dikeringkan di bawah sinar matahari hingga kering (kadar air kerupuk mentah $\pm 12 \%)$. 


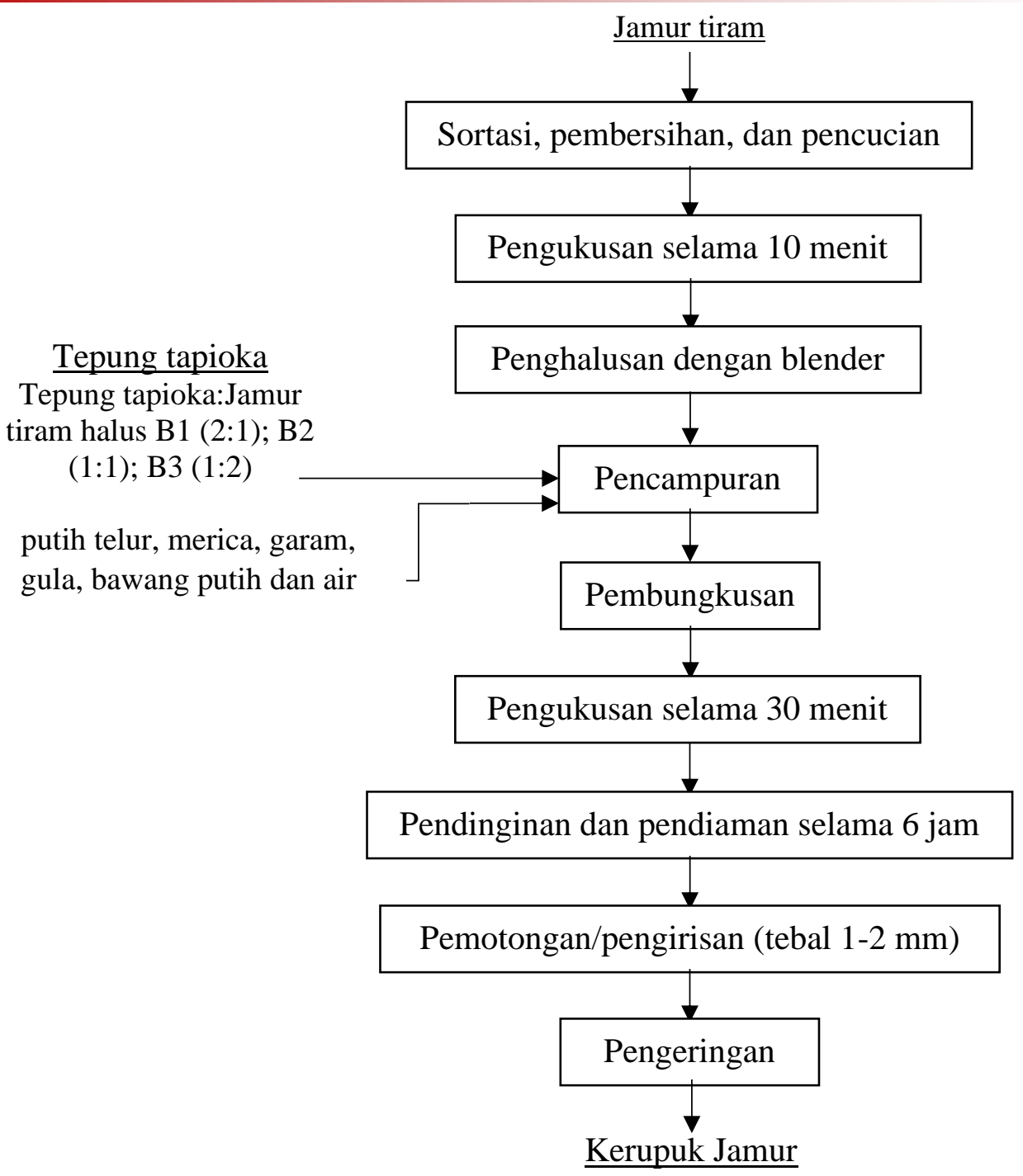

Gambar 2.1. Proses Pembuatan Kerupuk Jamur Tiram

\subsection{Rancangan Penelitian}

Penelitian ini menggunakan metode Rancangan Acak Kelompok (RAK) dengan faktor tunggal. Perlakuan penelitian ini adalah proposi tapioka dan jamur tiram sebanyak 3 taraf, yaitu B1 (2:1); B2 (1:1); B3 (1:2). Pengamatan yang dilakukan terhadap produk kerupuk jamur tiram ini meliputi volume pengembangan dan sifat organoleptik (warna, aroma, rasa, tekstur, dan kerenyahan) dengan metode deskripsi.

\section{Hasil dan Pembahasan}

\subsection{Volume pengembangan}

Hasil analisis menunjukkan bahwa perbandingan jamur tiram dengan tepung tapioka memberikan pengaruh nyata terhadap volume pengembangan kerupuk jamur tiram (Tabel $3.1)$. 
Tabel 3.1. Volume Pengembangan Terhadap Kerupuk Jamur Tiram

\begin{tabular}{cc}
\hline Jumlah Jamur Tiram:Tapioka & Hasil Pengamatan \\
\hline $2: 1$ & Agak mengembang \\
$1: 1$ & Mengembang \\
$1: 2$ & Lebih mengembang \\
\hline
\end{tabular}

Semakin banyak jamur tiram ditambahkan tingkat pengembangan akan semakin menurun. Hal ini disebabkan kandungan protein dan serat dari jamur tiram lebih tinggi dibanding dengan pati tapioka. Komponen lain selain pati seperti serat, protein dapat mempengaruhi pengembangan kerupuk. Studi yang dilakukan oleh Yu (1991) menunjukkan bahwa adanya interaksi antara protein dan pati dapat menyebabkan proses pengembangan yang terhambat. Jamur tiram yang memiliki kandungan protein cukup besar dapat mempengaruhi pengembangan pati pada kerupuk tersebut.

\subsection{Aroma}

Aroma adalah salah satu sifat organoleptik yang penilaiannya mengunakan indera penciuman. Aroma pada suatu produk dapat ditimbulkan dari bahan baku utama produk tersebut, namun tidak hanya itu aroma juga bisa ditimbulkan oleh bahan tambahan yang tertentu yang menimbulkan bau khas dan dipengaruhi oleh perbandingan dari berbagai bahan yang digunakan.

Penambahan jamur tiram dan tepung tapioka mempengaruhi terhadap aroma kerupuk walaupun tidak begitu segnifikan. Semakin banyak jamur tiram di tambahkan makan aroma yang dihasilkan akan semakin tercium.

Tabel 3.2. Aroma Kerupuk Jamur Tiram

\begin{tabular}{cc}
\hline Perlakuan & Hasil Pengamatan \\
\hline $2: 1$ & Tercium khas jamur kuat \\
$1: 1$ & Tidak terlalu tercium khas jamurnya \\
$1: 2$ & Aroma jamur hilang \\
\hline
\end{tabular}

Menurut Cahyana et.al (1999), timbulnya aroma pada kerupuk jamur disebabkan oleh pemecahan asam-asam amino yang terdapat dalam jamur tiram putih yaitu lisin, triptofan, threonine, valin, leusin, isoleusin, histidine, dan fenilalanin. Pada Tabel 3.2 diatas terlihat perbedaan aroma kerupuk jamur dengan berbagai proporsi antara jamur tiram dengan tepung tapioka.

\subsection{Rasa}

Hasil pengamatan kerupuk jamur menunjukkan bahwa perbandingan jamur tiram dan tepung tapioka berpengaruh nyata terhadap rasa kerupuk. Perbedaan rasa disebabkan oleh perbedaan perbandingan antara jamur tiram dengan tepung tapioka. Semakin banyak jamur tiram yang ditambahkan maka rasa khas dari jamur tiramnya akan semakin kuat (Tabel 3.3). Rasa dinilai karena adanya tanggapan rangsangan kimiawi oleh indera pencicip, dimana akhirnya kesatuan interaksi antara sifat aroma, rasa dan tekstur meupakan penilaian dari keseluruhan rasa makanan yang dinilai (Winarno, 1984).

Berdasarkan pernyataan responden bahwa rasa yang paling disukai adalah perbandingan 1:2, karena rasa jamur tiramnya relatif tidak terasa. Rasa jamur tiram yang muncul pada kerupuk ini juga bisa dipengaruhi oleh proses pengolahannya yaitu 
menggunakan perebusan. Panelis lebih menyukai rasa jamur tiram yang diolah menggunakan teknik penggorengan dibandingkan perebusan (Sutikarini dkk, 2015).

Tabel 3.3. Rasa Kerupuk Jamur Tiram

\begin{tabular}{cc}
\hline Perlakuan & Hasil pengamatan \\
\hline $2: 1$ & Asin, gurih dan jamurnya begitu menyengat \\
$1: 1$ & Rasa asin sedang dan cukup gurih \\
$1: 2$ & Gurih, tidak terlalu asin dan tidak terlalu terasa jamur \\
\hline
\end{tabular}

\subsection{Tekstur}

Hasil pengamatan kerupuk jamur menunjukkan bahwa perbandingan jamur tiram dan tepung tapioka berpengaruh nyata terhadap tekstur kerupuk (Tabel 3.4).

Tabel 3.4. Tekstur Kerupuk Jamur Tiram

\begin{tabular}{cc}
\hline Perlakuan & Hasil Pengamatan \\
\hline $2: 1$ & Renyah tetapi bagian tengah agak keras dan porinya rapat \\
$1: 1$ & Ketika digoreng permukaannya agak halus tapi alot \\
$1: 2$ & Renyah dan lumer dimulut tetapi cukup rapuh porinya cukup besar \\
\hline
\end{tabular}

Perbedaan tekstur kerupuk jamur tiram disebabkan karena kadar air, kadar protein, dan volume pengembangan yang berbeda. Menurut Muchtadi et.al (1988) kandungan air yang tinggi dalam bahan makanan akan menghambat proses pengembangan produk, sehingga tekstur yang dihasilkan menjadi kurang kering dan kurang renyah. Penambahan pati yang cukup tinggi dari tepung tapioka menyebabkan terjadinya proses gelatinisasi. Pati yang tergelatinisasi akan menghasilkan pemecahan sel pati yang lebih besar selama penggorengan. Komponen lain selain pati seperti serat, protein dapat mempengaruhi pengembangan kerupuk. Studi yang dilakukan oleh Yu (1991) menunjukkan bahwa adanya interaksi antara_protein dan pati dapat menyebabkan proses pengembangan yang terhambat. Jamur tiram yang memiliki kandungan protein cukup besar dapat mempengaruhi pengembangan pati pada kerupuk tersebut

\section{Kesimpulan}

Perbandingan jamur tiram dan tapioka pada pembuatan kerupuk mempengaruhi volume pengembangan dan sifat organoleptic kerupuk yang dihasilkan. Hasil penelitian ini menunjukkan bahw perlakuan terbaik untuk kualitas kerupuk jamur tiram adalah proporsi jamur tiram dan tepung tapioka berturut-turut yaitu 1:2. Semakin banyak tepung tapioka ditambahkan volume pengembangan pun akan semakin besar serta pori-pori yang dihasilkan sangat terlihat sehingga ketika digigit lumer di mulut.

\section{Pustaka}

Ardiansyah. 2013. Metode Pembuatan Tepung Jamur Tiram (Pleurotus oestreatus) Terhadap Sifat Fungsional Tepung Jamur Tiram Putih. Skripsi. Universitas Lampung. Bandar Lampung. 
Cahyana Y. A et.al. 1999. Jamur Tiram (Pembibitan, Pembudidayaan, Analisis Usaha). Jakarta: Penebar Swadaya.

Herdritomo, H. I., D. Tjokrokusumo, dan I. Djajanegara. 2008. "Pengaruh Mutase Radiasi Sinar Gamma (Co60) Terhadap Produksi Jamur Tiram Putih (Pleurotus oestreatus)", dalam Jurnal Biotika. Vol. 6, No. 1: 8-14.

Martawijaya, E.I. dan M.Y. Nurjayadi. 2010. Bisnis Jamur Tiram di Rumah Sendiri. Bogor: IPB Press.

Muchtadi, TR., P et.al. 1988. Teknologi Pemasakan Ekstrusi. Bogor: Institut Pertanian Bogor.

Nurainy et.al. 2015. "Pengaruh Tapioka dan Tepung Jamur Pada Kerupuk", dalam Jurnal Teknologi Industri dan Hasil Pertanian. Vol. 20, No 1: 2015.

Sutikarini, Sri Anggrahini, dan Eni Harmayani. 2015. "Perubahan Komposisi Kimia dan Sifat Organoleptik Jamur Tiram Putih (Pleurotus ostreatus) Selama Pengolahan", dalam J. Ilmiah Agrosains Tropis. Vol. 8, No. 6: 261-271.

Sutrisno, Koswara. 2009. Pengolahan Aneka Kerupuk. Ebookpangan.com

Tabita D. 1992. Pengaruh Berbagai Taraf Perbandingan Tapioka dan Tepung Biji Durian Terhadap Sifat Kerupuk Durian (Durio zibethinus). Skipsi. Lampung. Universitas Lampung. Bandar Lampung

Winarno, F.G., 1997. Pangan, Gizi, Teknologi dan Konsumen. Jakarta: PT Gramedia Pustaka Utama. 